\title{
分譲マンション建替の合意形成プロセスに関する研究 \\ 一首都圈における実現事例を対象として一 \\ A STUDY ON THE PROCESS OF CONSENSUS BUILDING ON RECONSTRUCTION OF CONDOMINIUMS \\ - Case studies in the metropolitan area-
}

\author{
米野史健*
}

Fumitake MENO

\begin{abstract}
Deterioration of condominium buildings and facilities will become social problems, and reconstruction will be necessary in the future. Consensus among all unit owners of condominium is need to realize reconstruction, but consensus building is very difficult. Therefore, it is important to establish the method of consensus. In this study, I investigated 13 cases of reconstruction and examined the process and mechanism of consensus building. Following points are analyzed :

1) processes of the consensus building ; 2) issues on the process ; 3) mechanism of consensus building ; 4) roles of leading group.
\end{abstract}

Keywords : Condominium, Reconstruction, Consensus Building マンション、建替、合意形成

\section{1. 研究の背晨と目的}

分譲マンション（区分所有集合住宅）は都市部を中心としてこれ までに全国で 250 万戸以上が供給されており、現在では典型的な都 市住宅となっている。このうち供給初期の物件は建設から数十年を 経ており、建物・設備の老朽化が問題となりはじめている。コンク リート造のマンションでは維持・修繥を適切に行うことで設備や躯 体の急激な少化を防ぎ長期にわたる建物の利用は可能である。しか しそれでも劣化は徐々に進行していき長期的には建物は利用不可能 となるため、何らかの形での最終的な建替・更新は必要といえる。

しかし建替という改善策は修繥以上の多額の費用が必要であり、 この負担が問題である。また物件によっては建設後の容積率指定の 変更等のため既存不適格となり、建替時には従前と同じ床面積を確 保できないものもある。このような物件では建物形状の大幅な変更 や一部所有者の転出等が必要であり、費用はさらに多額となる。以 上の建築的・経済的な制約は、所有者間の合意を困難にする。分譲 マンションは敷地・建物を区分所有しているため、所有者の少なく とも 5 分の 4 以上の賛成がなければ建替事業は実施出来ない。多種 多様な所有者の合意を取ることは非常に手間と時間のかかる作業で あり、まして事業の条件が悪い物件においては事業に反対するもの が多くあらわれ、合意形成はさらに困難になると予想される。
この合意の問題は、分譲マンションが区分所有である以上、建替 に限らず維持管理・修繥においても避けては通れないものである。 このため区分所有者は管理組合を結成し集団での判断・行動を行う 形をとるが、個々の所有者の維持管理に対する意識の低さや所有者 全体での意思決定の経験不足により、通常の維持修繥でも合意が難 しいのが実情である。まして建替という居住及び凟産の大きな変化 を伴う場合にはさらに困難となろう。合意が出来ず建替が実現しな い場合、建物の住環境は悪化し居住者の生活に影響を及ほすだけで なく、資産面でも佃値の急激な低下などの問題が発生すると思われ る。問題を回避するためには、日常的な維持・修繥の実施を前提と した上で、建替における合意形成の方法を確立させる必要がある。

これらの視点からマンション建替に関する先行研究をみると、事 例分析 ${ }^{12}{ }^{2}$ ) 初期供給物件の実態調査 ${ }^{3)}$ 、建替傾向の推定 ${ }^{4)}$ 等がある が、合意形成を分析する論文は少ない。マンション管理研究におい ても管理活動の実態や所有者の管理意識、修綞工事の実施状沉等に 関する調査分析は多くみられるが5)、区分所有者間での意思決定・合 意形成に着目したものはあまりない註1。一方、建替における区分所 有者間での合意形成を住民の協同による新規建物の計画として捉え ると、建築計画分野でのユーザー参加による設計や、都市計画分野 での住民参加による計画策定とも通じるものとみることが出来る。

* 東京工業大学大学院社会工学尃攻 大学院生·工修 Graduate Student, Dept. of Social Engineering, Tokyo Institute of Technology, M. Eng. 
これらの分野では、前者でのコーポラティブ住宅のや後者のまちづ くりクタの研究にみられるように、参加や合意を一連のプロセスとし て捉え、そこに関わる主体間の関係・行動を分析する方法が近年多 くみられる。この方法は合意形成の動態を明らかにし、過程におけ る問題及びそれを解決するための手段を検討するものであり、これ らの視点はマンションの問題を扱う際にも有効と思われる。

そこで本研究では、建替事業を分襄マンションにおける維持管理 の最終的な局面として捉え、そこでの区分所有者間での合意形成の 動態を把握するためプロセスに着目して分析を行う。これにより区 分所有者間での合意形成の実態を把握するとともに、その過程で生 じる問題とその要因・解決策を考察する。

\section{2. 研究の望組}

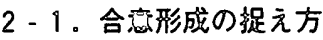

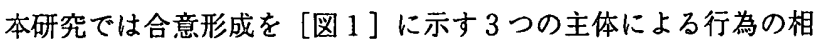
互作用の過程として捉える。まず建替事業において中心的に活動す る人々の集まりを「推進組織」とする。これは建替を積極的に進め ようとする区分所有者や管理組合・自治会の役員等で構成されるも ので、計画内容の検討や所有者への説明、所有者間の意見調整、反 対する所有者の説得、外部の業者等との折衝などの役割を担う。

推進組織以外の区分所有者は「一般所有者」とする。一般所有者 は個々の価値観や事情に基ついて建替に対する意向を形成し、推進 組織に対して事業への賛否や要望などを提示する。これらの区分所 有者のうち、実際に住戸に居住するものを「居住所有者」、居住はせ ず質貸等に利用する所有者を「不在所有者」、会社で所有し社宅等と して利用する所有者を「法人所有者」と表記する。

区分所有者の他、外部から事業に参加・協力する主体を「外部団 体」とする。これには推進組織を支援する設計事務所・コンサルタ ントや、事業を請け負うデベロッパー、建物の設計・施工を行う建 設業者などがある。外部団体は推進組織から意見・要望を受け、そ れに対して計画の提案や活動への助言などを行う。

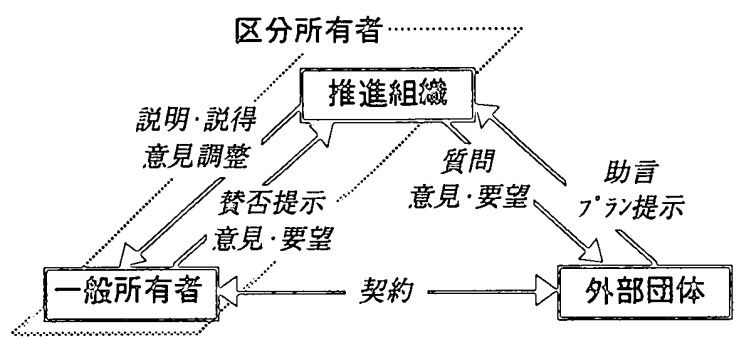

図 1：合意形成に関わる主体及びその関係

またこれら主体による合意形成は [図 2] に示す 3 種の要素から なるモデルとして記述する。まず主体 1 が形成した意見が他の主体 2 に対して「提示」され、この意見を巡って主体間での意見の「交 流」がなされる。交流では、最初の意見に対して主体 2 が自分の意 見を形成して提示、これを受け主体 1 が自らの意見を変更して提示 するかまたは再度自身の意見を提示する。同様に意見の変更または 再提示が行われ、この相互作用の過程で両者の意見が变化し互いに 受け入れられるものになったとき、あるいは一方が他方の意見を受 け入れたとき、両者の間での「合意」が成立するとする。

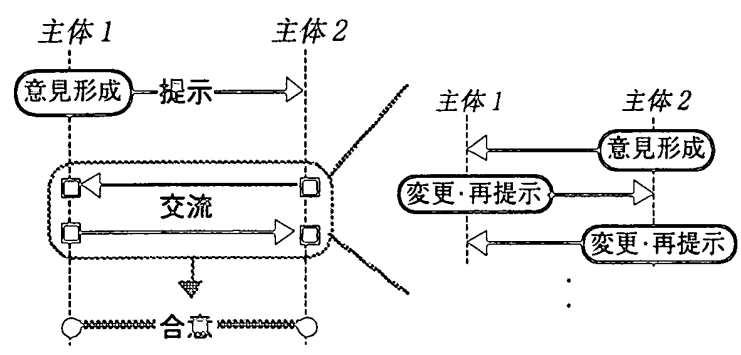

図 2：合意形成の記述モデル

\section{2-2。調䆟。分新の方法}

対奥は首都圈において過去10年程の間に実施された複数の建替事 業とする。複数とするのは様々なタイプの合意形成過程を比較する ことで今後の建替で起こりうる状況を考察するためである。既存の 調㚗研究 9) 10) 及び新聞・雑誌記事等より事例を収集し、このうち協 力が得られたもので調㸖を実施した。調宜では推進組織で主要なメ ンバーとして活動した人物、及び外部団体のうち合意形成に中心的 に関わったデベロッパーの担当者に対しヒアリングを行った註21。こ のほか事実関係を詳しく把握するため、事業過程で使用された資料 や過程をまとめた文献等の収集を行った。

これらの情報をまとめ、各事例で合意形成がどの主体間でどのよ うな方法で行われたか、及び相互に交わされる意見がどう変化した かをまとめる。整理されたプロセスより合意上の主要な論点を抽出 し、その論点毎に合意を形成するメカニズムについて分析を行う。

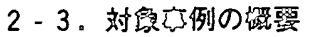

[表 1] に示す 13 の事例が対象である。これらの多くは昭和 30 年 代に住宅公団等の公共主体が建設した団地形式のもので、法定容䅪 率 $200 \%$ の第 2 種住居䙳用地域（建替当時の指定）に位置する。敷地 面榬は平均 $5400 \mathrm{~m}^{2}$ であり民間のマンションと比べて大きいが、団地 としては比較的小さい。従前建物の建設後約 30 年程で建替が発意さ れ、事業の終了までに平均 6.3 年の期間をかけている。事例 $\mathrm{B}$ を除く 全ての事例で等価交換方式が用いられており、容積の余裕を活用し て住戸を増やし新規に分譲することで事業を実現している。同時に 従前の狭い住戸高有面積も増加させており、等価交換により無㑽で 還元される面積をさらに増やす場合を除き、事例 B以外では所有者 による費用負担は基本的に必要ないものとなっている。事業は最終 的には全員合意によって行われており、区分所有法に基づく建替決 諓（所有者の 5 分の 4 以上の賛成）によるものではない。

表 1：対奥事例の概要

\begin{tabular}{|c|c|c|c|c|c|c|c|c|c|c|c|c|c|}
\hline 要 & & 狚地 & & 前建牛 & & 建聙 & 萶建物 & & & 所有 & 者殉 & & 期 \\
\hline 例 & 所在地 & 面䖽 & $\begin{array}{l}\text { 延床 } \\
\text { 面积 }\end{array}$ & 可 & $\begin{array}{l}\text { 住畐 } \\
\text { 面积 }\end{array}$ & $\begin{array}{l}\text { 延床 } \\
\text { 面积 }\end{array}$ & $\begin{array}{l}\bar{P} \\
\text { 敛 }\end{array}$ & \begin{tabular}{|l|} 
住戸 \\
面积
\end{tabular} & \begin{tabular}{|l|} 
就 \\
致
\end{tabular} & $\begin{array}{l}\text { 居 } \\
\text { 住 }\end{array}$ & $\begin{array}{l}\text { 不 } \\
\text { 在 }\end{array}$ & 法 & 間 \\
\hline $\bar{A}$ & 東京都目黒区 & 5526 & 2913 & 68 & 35 & 6979 & 98 & 62 & 35 & 12 & 12 & 11 & $\overline{4.4}$ \\
\hline B & 軎京都新宿区 & 1505 & 1506 & 24 & 49 & 2100 & 23 & $\overline{77}$ & 24 & 12 & 12 & 0 & 3.8 \\
\hline $\mathrm{C}$ & 賁京都中野区 & 3441 & 4055 & 60 & 45 & 6723 & 81 & 67 & 42 & & - & 12 & 12.1 \\
\hline D & 葘京都大田区 & 8525 & 5974 & 105 & 52 & 15337 & 131 & 83 & 67 & 28 & 25 & 14 & 9.6 \\
\hline $\bar{E}$ & 硔浜市港北区 & 853 & 1023 & 18 & 44 & 1691 & 30 & 54 & 18 & 16 & 2 & 0 & 2.6 \\
\hline F & 神奈川県相模原市 & 4298 & 3268 & 72 & 35 & 8374 & 122 & 61 & 72 & 53 & 17 & 2 & 4.8 \\
\hline $\bar{G}$ & 菄京都品川区 & 1449 & 1014 & 16 & 53 & 28 & 27 & 81 & 15 & 5 & 8 & 2 & 7.5 \\
\hline $\mathrm{H}$ & 曺京都世田谷区 & 7254 & 3176 & 56 & 40 & 9013 & 72 & 100 & 38 & 21 & - & 10 & 7.3 \\
\hline I & 茨城県古河市 & 5699 & 3680 & 64 & 48 & 11399 & 164 & 75 & 58 & 37 & 18 & 3 & 3.8 \\
\hline $\bar{J}$ & 神奈川県婉倉市 & 9558 & 4489 & 114 & 39 & 14745 & 140 & 90 & 99 & 47 & 24 & 17 & 6.7 \\
\hline $\bar{K}$ & 神寮川県相模原市 & 3043 & 2495 & 48 & 49 & 5940 & 80 & 68 & 45 & 44 & & 0 & 5.7 \\
\hline L & 東京都世田谷区 & 11603 & 7327 & 156 & 42 & 27850 & 226 & 82 & 96 & 45 & 30 & 21 & 7.0 \\
\hline$\overline{\mathrm{M}}$ & & 7517 & 5885 & 135 & 37 & 24955 & 271 & 70 & 47 & 10 & 18 & 19 & 70 \\
\hline
\end{tabular}


従前建物での所有者数をみると、居住所有者が半数に満たず不在 所有者の割合が大きい事例が多い。また法人所有者も多く、戸数と の比較より多数の住戸を所有しているのがわかる。従前の管理では 所有者自らが管理を行う自主管理の形態をとるものが多い。所有者 組織として管理組合という形態をとらない事例もあり、これらでは 居住者による自治会が管理を行っている。

\section{3. 合意形成のプロセス}

\section{3-1.プロセスの概要}

合意形成に関わる 3 主体の関係、及び主体間での提示・交流・合 意の内容を整理すると、事業終了までの過程は複数の個別課題への 合意が積み重なって構成されているといえる。この個々の合意形成 で過程を分割すると、過程は以下に示す期及び段階を経て進むと考 えられる。各期での一般的なプロセスを［図3～5］に示す。

各事例毎の状況を説明するため、以降の記述及び図中では該当す る事例名を括弧内に記す。なお事業の一時停止により検討・計画期 の合意形成を複数回行ったもので、回数により合意形成の形式が異 なる場合には、事例名に数字を付加してその違いを表記する。

\section{1) 検討期}

\section{【組織形成】}

特定の区分所有者から建替が発意されプロセスが始まる。発意は 居住所有者、特に主婦層が老朽化した設備及び住戸の狭さへの不満 から提案するものが多い。また管理組合・自治会の役員が修綁の問 題に直面し解決策として建替を提案した場合も半数近い。デベロッ パーからの打診がきっかけで検討が始まった事例もある (L,M)。

これらの発意はまず役員に伝えられ意見交流が行われる。この過 程では建替の必要性を詳しく説いたり、具体的な情報を提供するこ とで検討開始への理解を得ている。理解が得られた場合は役員内で の検討が始まるが、得られない場合には居住者有志による勉強会が 開催され (A,F,G,J,M)、これが推進組織の役割を担うこととなる。 【構想検討】

どのような建替が可能であるか、事業の構想が検討される。この 策定のため、多くの事例で外部団体への支援要請が行われている。 依頼先は管理会社等が紹介の設計事務所 $(\mathrm{A}, \mathrm{B}, \mathrm{C}) 、$ 知人を通じての建 設業者 $(\mathrm{D}, \mathrm{G}, \mathrm{I})$ 、建替経験のあるデベロッパー $(\mathrm{F}, \mathrm{J}, \mathrm{K})$ などである。 この場合、外部団体から等価交換等に関する情報・知識が提供され、 質疑を通じ推進組織内での建替への共通理解が得られている。その 後建替後建物の規模や事業費用の概算等が提示され、推進組織と外 部団体とが定期的に会合を行う形で意見交流がなされる。しかし内 容に関する議論や構想の変更などはあまりみられず、外部団体が提 示した構想をそのまま一般所有者に提示するものもある。

このほか依頼をせずに推進組織が独自で検討する事例 (D1,E,H1) や、外部組織への依頼の前に推進組織が修繥との比較や複数の建替 案の検討を行う事例 $(\mathrm{E}, \mathrm{G}, \mathrm{I})$ 、外部団体からの情報提供を受け推進組 織が検討する事例 (D2,H2,I,L) もある。

これらの過程を経て、推進組織内または推進組織と外部団体との 間で、構想案の内容及び事業の方針が確認される。

【方針認可】

建替の方針が推進組織から一般所有者に提示される。方針提示の 際は建替自体の賛否のみを聞く場合と、構想案を提示し内容を問う
場合とに分かれる。前者では意見交流は主にアンケートを用いて、 後者では構想の説明及び意見交流は管理組合総会等の場を利用した 説明会により行われている。個別に所有者を訪れて説明するものも あり (A,J,M 等)、特に法人に対してこの形をとっている。

提案に対し多くの所有者は消極的な賛成を示すが、不在・法人所 有者や高齡者等から疑問や反对意見が提示される。これらへはより 詳しい説明をすることなどで総論での賛成を得ている。

基本的な合意が取れると本格的な取り組みのための公式組織が設 立される。主に管理組合・自治会内の委員会という形式をとり総会 で委員の選出が行われるが、先の推進組織のメンバーがそのまま選 出される場合が多く、形式は変わっても実質的に変化はない。

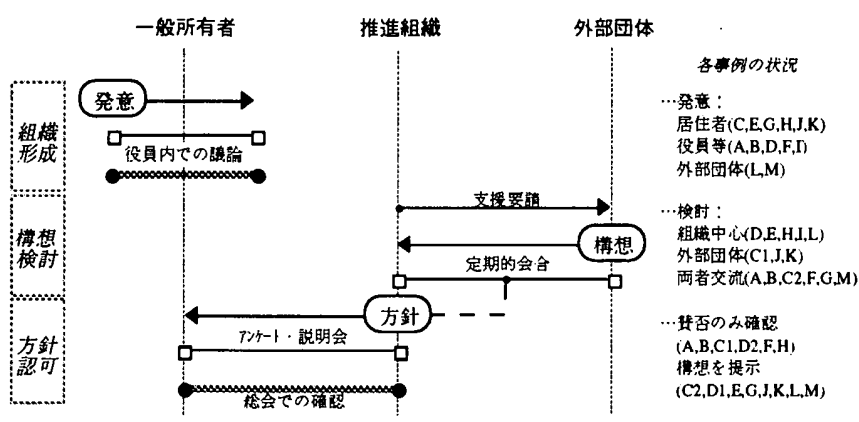

図 3 : 検討期での一般的プロセス

\section{2) 計画期}

【計画策定】

具体的なプランを検討するため、外部の業者等に計画案の策定が 依頼される。依頼は特定の単一業者の場合と複数の業者に行われる 場合とがあり、単一の場合は大半が検討期に支援を受けていた外部 団体、またはこれらより紹介を受けた業者への特命の形である。複 数の場合は業者が提示した計画案を推進組織が比較検討し、最もよ いと思われるものを選定するコンペ形式をとっている。

特命形式では、所有者側より提示された意向・条件等をもとにす る(A,I,J)などして業者が作成した計画案に関し、推進組織及び一般 所有者との間で意見交流がなされる。ここで出された意見を推進組 織がまとめて外部団体に提示するものが多い。これらの意見を取り 入れるなどして変更がなされ、計画案への基本了解が得られた時点

で、推進組織と外部団体間で合意が確認される。

コンペ形式では、最初に策定を依頼する業者への提示条件がまと められている。依頼する業者は一般所有者から推薦を募るものと $(\mathrm{C} 1, \mathrm{H}, \mathrm{L}) 、$ 推准組織が選定するものとがある (D,E,M)。この条件に基 づいて提示された計画案は、主に推進組織を对象として業者による 説明がなされ意見交流が行われる。計画案及び業者の選定は組織内 での合議 $(\mathrm{E}, \mathrm{L})$ または投票 $(\mathrm{Cl}, \mathrm{H} 1)$ で行われ、一般所有者が直接関 わるもの (D2,M2) は少ない。選定に際しコンサルタントを依頼した 事例 $(\mathrm{D} 2, \mathrm{H} 2)$ では、経済的内容から設計等まで含めた総合的な評価 が提示されており、所有者の判断に大きな影響を与えている。 【計画決定】

特命形式の場合はまとめられた計画案が、コンペ形式の場合は選 定された計画案と業者とが、書面や説明会を通じて一般所有者に伝 えられる。特に特命形式での説明会の開催回数は多く、プランが変 
更される度に直接所有者への説明がなされている(A,G,J等)。また推 進組織と業者とが各所有者を個別に訪問し説明及び意見の聴取を行 うものもみられる $(\mathrm{A}, \mathrm{L})$ 。これに対しコンぺ形式では、伝達及び意見 交換は拍面中心で行われる傾向がある。

提示された計画に対しては、内容への要望や進め方への不満、実 施そのものへの反対意見が出されている。これらの一般所有者から の意見に対しては主に推進組織により説明・説得が行われ、特命形 式では業者も説得に加わる場合がみられる(I,J,K)。

計画変更及び説得により合意が得られないと、計画は一時保留さ れ事業は停滞する。この場合これまでの活動や決定を一度保留した 上で、新たに合意形成をやり直す形で解決を図っている。

所有者が合意した段階でその内容が確認され、事業の実施が決ま る。この方法では総会等の場で全員の意思を確認するものが多い。 またこの時点で所有者と業者との間で協定を結び、合意を得た計画 内容で業者が事業を行うことを確認するものもある (E,G,I,K 等)。

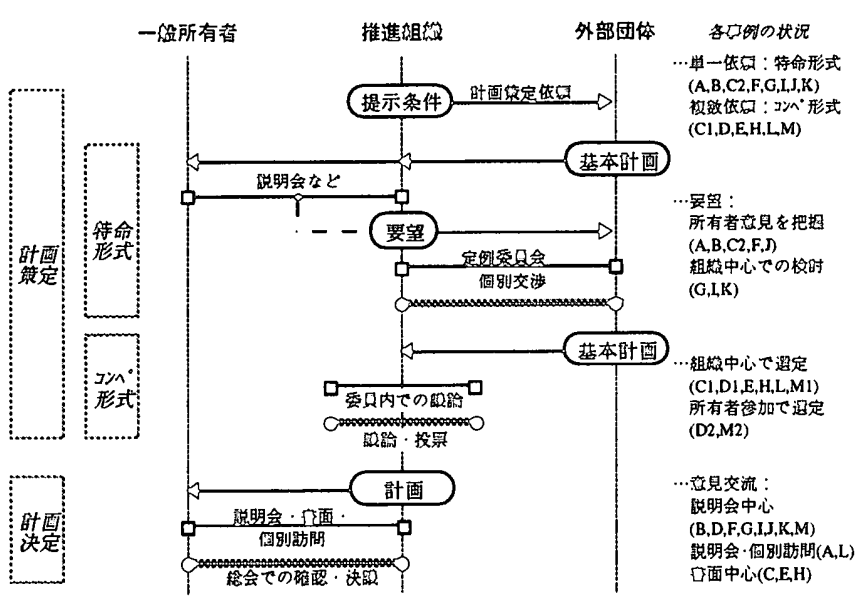

図 4 : 計画期での一般的プロセス

\section{3）実施期}

『設計変更】

実施設計が外部団体により作成され、これに関し主に一般所有者 と外部団体との間で意見交流がなされる。交流は特命形式のものに 多く、まずアンケートを実施し意向を把握して基本案を設計、これ を提示し出された意見を取り入れる形で何度も設計をやり直すなど、 細かい対応をしている $(\mathrm{A}, \mathrm{G}, \mathrm{I}, \mathrm{J})$ 。逆にコンペ形式では設計は基本的 に業者に任せ、提示されたプランをそのまま受け入れる傾向がみら れる $(\mathbb{D}, H, L) 。$ 意見は個々の間取りに関するものが大半であり、これ 以外への意見は少ない。こ机らの点に関して意見交流がなされ、基 本的に意見を受け入れる形で設計変更がなされ合意を得ている。 『住戸選定】

建替後建物での住戸位置の選定が行われる。従前と同じ位置を新 建物でも所有するようにした事例もあるが(E)、大半のものでは住戸 位置や広さによる価格差を設定した上で各所有者が希望を提示し、 無侻返還分との差額を還元または負担する形をとっている。この方 式で提示された希望は、位置は日照等の住環境が良い住戸に集中し、 広さでは無㑽返還面積程度の場合 (D等) とそれ以上の広い住戸を希 望する場合 (A,C,I,K等) とに分かれている。全体的には、比較的安 く設定される差額負担を活用し、多少の自己負担をしても広くて良
い住戸を求める傾向がみられる。

希望が重複した住戸では、所有者間で交涉が行われるとともに、 調整作業もなされる。調整は主に推進組織が行うが、業者にまかせ るものや両者が協力して行うものもある。この際には複数戸を所有 する法人を中心に協力を依頼する $(\mathrm{A}, \mathrm{J}, \mathrm{M}) 、$ 各所有者の事情を考虑し てふさわしい方への協調を求める (C) などの方法をとっている。こ の調整及び最終的な抽選により位置が決まるが、希望位置がとれな い場合に納得しない所有者が一部でみられる。この場合推進組織や 業者が何度も説得を行い、理解を得て問題を解決している。

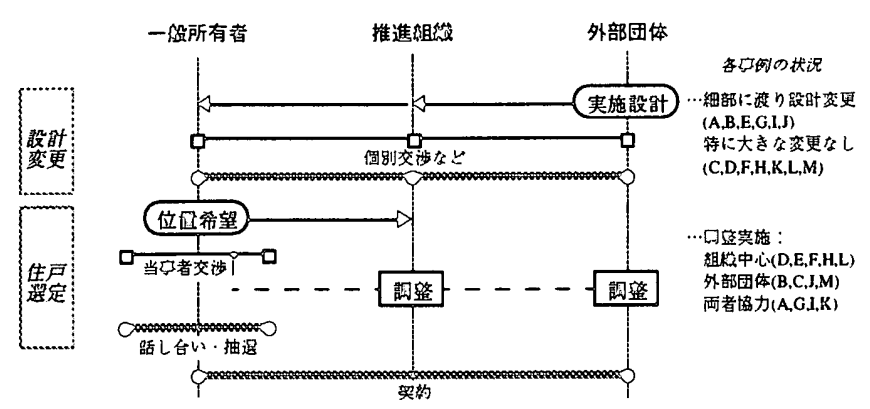

図 5：実施期での一般的プロセス

\section{4) 契約}

以上の各期の手続が終わると、所有者と業者の間で契約が締結さ れ事業全体への合意が確認される。この際に業者へ住戸の権利を売 却し、事業自体には参加しない所有者が全ての事例でみられる。壳 却される戸数は 1 ～16戸と様々であるが、平均では総戸数の $5 \%$ 程 度となっており、多いものではBで総戸效の 6 割、Hで 3 割が売却 されている。全体的には不在・法人所有者の売却する割合が高い。

売却理由は、不在・法人所有者では利用しないので資産を処分す るためが大半であり、複效戸を持つ所有者が一部を売却するもの (D,J 等) や、法人が社宅として適切でないため壳却するもの (H) 等 がある。居住所有者では建替終了まで待てないため $(\mathrm{J}, \mathbb{K})$ や他に住 み替えるため $(\mathrm{A}, \mathrm{F}) 、$ 高齢の所有者では子供との同居や相続のため (D,L) や仮住居にそのまま住み続けるため (E) 売却を行っている。

契約が全て終了し、居住者が仮の住居に転居した後建設工事が実 施され、建替が実現する。

\section{$3-2$ 。各行例の特瑢}

以上の過程に沿った形で事業は谁むが、個別の状況により進み方 及び合意形成の内容は異なっている。そこで各事例の特徴的なポイ ントを整理すると、次のようにまとめることが出来る。

『A】検討期に不在・法人所有者が建替の必要性を認めず反対を表明 したが、推進組織及び外部団体が個別の説明・説得を行ったことで 理解が得られている。計画期ではより広い無償変換面積や設計変更 が外部団体に求められ、意見を受け入れる形で合意している。 『B》条件が悪く自己負担が必要であったため事業に参加する所有者 と転出する所有者とが分かれ、転出分の権利を買い取る形で進めら れた。事業に賛同する所有者のみが残ったことから、コーポラティ ブ方式による参加者全貝での計画策定及び設計が行われている。 IC】推進組織主導の活動により大半の所有者が合意したが、一名が 業者決定に反対し感情的対立となったため事業が一時停滞した。再 
開後は組織を一新し交流を重梘するとともに、法人所有者への特命 の策定依頼により、問題を回避し実現へと至っている。

【D】十分な情報提示もなく計画を進めた推進組織に対して所有者が 反発し、新たな組織が形成された。新組織ではコンサルタントに協 力を依頼してコンぺを実施し、所有者意向を十分に反映した条件を 提示した上で、所有者の直接投票による選定を行っている。

【E】所有者数が少なく、また推進組織の中心人物が積極的に活動し たため、検討期での疑問や反对はほとんど出ずに合意が得られてい る。計画期以降でも個別の間取りへの要望が出ただけである。

【F】高齢者の反対に推進組織が対応しつつ計画策定まで至るが、構 想と異なり変換面積が狭くなったため合意が得られず、事業が一時 停滞した。再開後は業者の協力のもとで計画変更と説得を行い理解 が得られるが、最後まで業者選定に反対する所有者もいた。

【G】検討期の構想検討時に丁寧な説明を行い、疑問を提示する人々 の賛同を得ている。業者選定後の計画策定及び設計变更では、所有 者が内容への様々な要望を提示したため、外部団体との交涉に時間 がかかったが、最終的には意見を受け入れる形で決着している。

【H】推進組織が事業実現を急いだため所有者への対応が不十分とな り、業者選定方法等への反対から一時停止を余儀なくされた。以降 は情報提供を頻繁に行い、またコンぺ実施時にコンサルタントへ客 観的視点からの評価を依頼するなどして、合意を得ている。

【I】推進組織が強い力をもって事業を進め、検討期での反対に対し ても明確に内容を説明することで理解を得ている。組織の独断的な 姿勢を批判する声もあったが、表面化はせず合意に至っている。

【」】高齢者からの消極的な反対が多く、これらに対し建替の必要性 を説明するのに時間がかかっている。計画策定でも様々な要望が出 され、所有者全体で何度も議論を行い意見をまとめており、これら 意見を外部団体が最大限取り入れることで合意が成立している。

【K】検討期では建替への不安が多かったが、構想が提示され説明が なされると賛同者が増えている。計画内容に関しては特に問題とは ならず、残る反対者も経済的な利点を提示され合意している。

[L】高龄者からの疑問や住環境悪化への反対が出されているが、推 進組織が対話の中で反対理由を明確にし、その要因を解決するよう な構想・計画を策定することで合意を得ている。このため計画決定 等での内容の議論も比較的少なく済んでいる。

【M】多くの所有者が消極的ではあるが賛成の意思を示し、構想検討 までは順調に進んだ。しかしコンペ実施中に方法に対する異議が出 され、途中まで進んだ業者選定を中止し再度やり直している。

\section{3-3. 合意形成における論点}

以上の概要及び各事例の特徴から、合意形成における主要な論点 は「建替の是非」「計画の内容」「進行の手続」の 3 点といえる。

\section{1) 建替の是非}

建替事業自体の判断に関する論点であり、建替を提案する推進組 織とそれに疑問を呈する一般所有者との間で問題となる。この論点 は主に検討期において扱われるが、この時期に十分な合意形成が出 来ない場合には計画決定時においても争われる。

建替の提案は、給排水管や外壁等の設備の劣化が問題になったこ とから始まっている。修繥を行ったがすぐに別の個所の工事が必要 になる場合や $(\mathrm{A}, \mathrm{G})$ 、複数の問題がまとめて生じた場合 $(\mathrm{E}, \mathrm{F}, \mathrm{K})$ な
どである。このように修繥の費用がかさみ、また今後もさらに必要 になることから、工事にかける費用とその効果を考えると建替の方 が経済的であるとの判断により建替が選択されている。

この提案に対し多くの所有者は消極的な賛成を示すが、不在・法 人所有者が必要性を認めない $(A, C, G) 、$ 事業への疑問や不安を感じる $(\mathrm{H}, \mathrm{K}) 、$ 高歯者が変化を望まない $(\mathrm{J}, \mathrm{L})$ 等の理由から理解が得られな い事例もある。この他では推進組織への不信感からの感情的な反対 や $(\mathrm{H}, \mathrm{J}) 、$ 事業による管理費增加や住環境覀化への反対 $(\mathrm{L})$ 、専有部 分の工事をしたばかりで必要性を感じない $(G)$ 等がみられる。

計画期においても、事業による生活の変化を望まないとの高齢者 の声 $(\mathrm{F} 1, \mathrm{I}, \mathrm{J}, \mathrm{K})$ や、費用負担を不安に思う意見 $(\mathrm{E}, \mathrm{I}, \mathrm{K})$ 等、実施への 疑問が提示される。このほか専有部分をすでに改装した人や抵当権 の問題がある人、住宅を購入したばかりでまだ借金が残る人などか ら反対意見が出されている。

\section{2) 計画の内容}

建物全体の設計や事業計画等の経済面、間取りなどに関するもの である。主に計画期に扱われ、計画策定においては推進組織と外部 団体との間（特命形式）または推進組織内（コンペ形式）で、計画 決定では推進組織と一般所有者との間で議論がなされる。

特命形式での計画策定では、外部団体が所有者の要望や事業に関 わる各種条件を把握しその範囲内で策定した計画に対し、推進組織 が意見を提示する形となる。意見は等価交換における無償返還面積 に関してが中心で、これに関わる建設費や土地評価額、自己負担金 など経済的な項目への意見が多い $(\mathrm{A}, \mathrm{F}, \mathrm{K})$ 。同時に建物の配置など設 計案への意見も一部でみられる( $\mathrm{A}, \mathrm{C} 2)$ 。

コンペ形式では策定前に満たすべき基本条件が提示されるが、内 容としては特命の場合と同様、無償返還面積の広さや権利を買い取 る際の価格等、経済的な項目が中心である。案の選定に際しても無 償返還面積が最も重視される選定基準となっている (D2,E,H1 等)。

このプランが計画決定段階で提示されるが、内容に関して一般所 有者との間で議論が起きる。所有者の意見はより広い無償返還面積 (A,F 等) や増床負担の設定額、転居する際の権利の買取価格 (B 等)、 間取りの設計改善 (A,E,L) など、住戸部分の広さ及び資産価値など 主に専有部分に関するものが大半である。計画策定時での要望が満 たされていてもさらに良い条件を求める傾向がみられる(A,G等)。ま た推進組織が住棟全体の設計や設備について積極的な意見を提示す

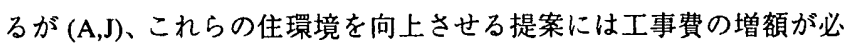
要であり無償変換面積の減少をもたらすため、資産価値を重視する 所有者との間で意見対立が生じている。

実施期の設計変更では間取りを中心に議論がなされ、いずれの事 例でも所有者は自分の意向を取り入れた自由な間取りを希望してい る。間取り以外への意見は少なく提案が受け入れられているが、共 用部分への意見 (J) や販売価格の要望 $(\mathrm{G})$ がみられる。前者は費用 低滅のためにはエレベーターと集会場が不必要との意見、後者は等 価交換時の設定価格より販売洒格を下げないようにとの要望である。 3) 進行の手続

事業の進め方や推進組織の行動そのものに関する論点である。主 に一般所有者と推進組織との間で扱われ、話が具体的に進む計画期 及び実施期になって問題となっている。

特に計画期の計画決定時に事業の進め方への反対が数多く出され 
ている。選ばれた業者に問題ありとの意見や (C12,F12)、推進組織と 業者が忿着しているとの指摘など (D1,I)、業者選定を中心とした意 見が多い。この他コンペ形式では推進組織のみによる計画案選定へ の異裁 $(\mathrm{Cl}, \mathrm{H} 1)$ や手続の不備の指摘 $(\mathrm{H} 1, \mathrm{M} 1)$ などが提示されている。

このほかでは、情報の提供や計画への意向取入の不足など、所有 者への対応上の問題が指摘される。情報提供では構想・計画の説明 が不十分であることや、外部団体との交涉の内容や推進組織の活動 実態を報告しないこと $(\mathrm{D} 1, \mathbb{I})$ が指摘される。意向の取入では計画内 容に所有者の意向が反映されていないこと、コンぺ形式での推進組 織による判断に意見が活かされていないこと $(\mathrm{H} 1)$ の指摘である。

また合意を確認する方法について所有者から異論が出されたり、 検討期で同意を得ているのに塞施への反対が計画期に再度提示され る $(\mathbb{I}, \mathrm{J}, \mathbb{K}) 、$ 合意確認の後になって反対意見户不満を提示する所有者 がいる (C2,I,K) などの問題が生じるものもみられる。

実施期の住戸選定では、希望位置がとれない場合に選定方法に異 誐を唱え、自分の主張を押し通そうとする行為が一部でみられる。従 前と同じ位置とする原則を無視して希望を主張する (E)、希望が重複 した所有者同士が互いに位置を変えようとしない(G)、抽選に外れた 後も結果を受け入れない (I) などである。

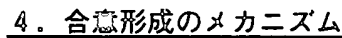

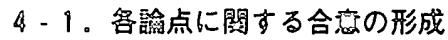

プロセスでの3つの主要な論点に関し、なぜその点が問題となる か、及び合意がどのように形成されているかを分析する。各論点に おける合意形成の過程を模式的に表したのが [図 6〜8] である。

\section{1) 建替の是非}

実施への疑問・反対は、主に不在・法人所有者及び高齢の居住所 有者から提示されている。不在・法人所有者は実際に居住していな いため老朽化の現状を知らず必要性を感じないためといえる。高龄 者の場合は建替により住環境が改善されることよりも事業実施によ る煩わしさや生活の变化を嫌う傾向がみられる。このような状況認 識・価値観の相違から異論が生じると考えられる。

この点に関しては、主に説明・説得による対応がとられている。状 況認識の相違は、構想や計画の具体的な内容を説明し今後の見通し を明確にすることで解消が図られている。推進組織と一般所有者と の間での細かい議論が行われたり、外部団体による計画内容の説明 会を何度も開催するなど、より積極的な交流を伴う場合が典型的で

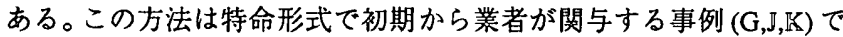
多く、当初から一貫して関わることで可能になっている。価值観に 関しては、経済的に有利であるという説明がなされる。不在・法人 所有者には資産価値が向上すること、高齢者には現状以上の面䅪が

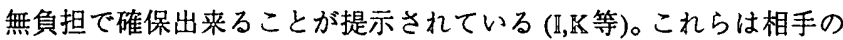
意見を理解し説明するというよりは、説得者側の価値観のもとで話 を進めて同意させる対応がとられているといえる。このほか、多く の所有者が希望しているので協力してほしいとの心情的な説得がな される。これらは強く反対する高齢者や住戸選定で希望位置を变え ようとしない所有者等に対し個別訪問で行われる場合が多く、直接 会って話すことで理解を得ようとしている。また仮住居の手当て等 での協力を約束する $(\mathrm{J}, \mathrm{L})$ 、不安に思う点を解消する内容を計画に盛 り込む (A,L等) などの条件交涉も行われる。
以上の説明・説得により、最終的に建替の必要性に関する了解を 得ることで合意が成立している。心情的な形でも同意が得られてお り、他の所有者が希望するなら同意する $(\mathrm{HI}) 、$ 推進組織・外部団体 が信頼出来るからとの理由で納得するなど $(\mathrm{A}, \mathrm{C} 2)$ 、主体間での人間 関係が影響を及ほしている。推進組織と一般所有者の交流の度合が 強い事例で互いに信頼関係が生まれており、この点からもきめ細か な対応が効果的であるといえる。また少数の反対者に対して区分所 有法に基づく建替決識要件（5分の 4 以上の賛成で可決）を提示す ることにより、法の規定が間接的に心理面への影響を及はし同意に つながったとみられる事例もある (C2,J)。ただしこれらの了解は栍 極的に賛成するのではなく、自分に負荷がかからないなら認めると いう消極的なものが多い。これは等価交換により基本的には負担が ないという事業条件であったからこそ成り立ったといえる。

しかし了解や同意はするが最終的には住戸の権利を売却し事業に 参加しない所有者もみられる。これは提示された事業条件が所有者 側の希望を満たさない場合や、所有者の求める生活が計画内容と大 きく異なる場合、事業に伴う税負担・諸手続を所有者が嫌う場合な どである。この対応は価値観や計画への意見の根本的な違いを解消 することを避け、あえて不参加という形をとることで最終的に問題 を解決しようとするものといえる。

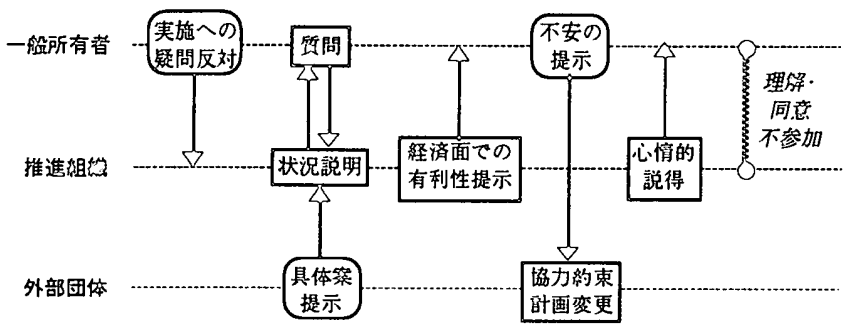

図 6：「建替の是非」に関する合意形成

\section{2) 計画の内容}

一般所有者及び推進組織から提示される様々な意見・要望は、無 償変換面積の広さや権利売却の設定額等の経済的内容と、間取り設 計や住戸位置等の住戸部分に関するものに大別される。前者は住居 を資産価値として捉える意識、後者は居住の場所として捉える意識 から生じるといえる。この両者の意識の間で判断がされるわけであ るが、所有者の属性によって志向が異なる。居住所有者の場合資産 性より居住性を重視し、住環境が向上するのであれば多少の負担·資 産減少は受け入れる志向がみられる。特に推進組織として事業を進 める所有者にこの傾向が強い。これに対し不在・法人所有者は資産 価値を重視し、事業によって価値が低下するなら参加しないとの意 思を示す場合もある。

事前の意向調査や提示条件を受けた計画では意見は少なく、外部 団体が提示する内容と推進組織・一般所有者の希望がかけ離れてい る場合に多くの要望が提示されている。特に当初の構想の条件がよ い場合所有者が建替に過大な期待を抱くため、後の現実的な内容上 の間でギャップが生じ反対はより大きくなっている。また先に提示 した要望を満たす計画でもさらに意見が出されるなど、自らにとっ て出来るだけ条件の良い住戸を求める傾向もみられる。

これらの計画内容に関する論点では、外部団体により所有者の意 
向を可能な範囲で計画に取り入れる形で交流が行われている。意見 を受けて再度事業計画を練り直すほか、建物全体や間取りの設計を 変更するなどを行っている。特に間取りの設計では、意見をもとに 多様な間取りパターンを設計する $(\mathrm{A}, \mathrm{G}, \mathrm{I}, \mathrm{J}, \mathrm{K})$ 、部分的に設備等への 意見を取り入れる (C,D,F,L)、内装等の細部まで対応する $(\mathrm{B}, \mathrm{E}, \mathrm{G}, \mathrm{J})$ などと細かい対応をしている。これにより所有者の意向を取り入れ ていなかったプランを改善し、要望と計画内容とのギャップを埋め る形で解決が図られている。ただし外部団体が計画期に所有者の意 見を反映させたものでは、実施期においても多数の意見が出される 傾向があり $(\mathrm{A}, \mathrm{J})$ 、意見を取り入れるという外部団体の協力姿勢が所 有者に要求を提示させやすくする面もみられる。

一般所有者と推進組織の要望とが食い違う場合、一般所有者の意 見が重視されている。これは推進組織が所有者の意見を調整する役 割を担っているため、全員の合意をとるためには一般所有者の意見 を受け入れる方を選択するからであり、また自らの意見を重視する ことが一般所有者の反発を招くことを恐れるからである。この結果 推進組織が望んでいた住環境の向上が果たせない場合がみられる。

意見取入の他では、詳しい情報の提供により理解を得る対応がな される。外部団体が推進組織に物件のおかれた条件を説明、提示し たプランが現実として最適なものであることを示している。このよ うに両者の交流関係を深くすることで計画に対する認識が共有され るとともに、信頼関係が築かれ相手の意見を認めるようになってい る。この結果推進組織が計画の变更が得られないことを了解した場 合には、今度は一般所有者への説明の役割を担うこととなる。

これらの対応で、計画の変更により双方が受け入れられる内容に なったこと、及び所有者側が内容を理解したことで合意が成立して いる。外部団体が計画変更を受け入れ、推進組織・一般所有者が自 らの主張を取り下げるなど互いに妥協しているが、最終的に外部団 体が所有者側の意見を受け入れたものが多い。特に返還面積等の事 業面に関し、工事費用の見直しや利益幅の圧縮等の企業努力により 変更が行われたり $(\mathrm{A}, \mathrm{C} 2, \mathrm{~K}) 、$ 費用低減のためエレベーターや集会室 等の共有設備を縮小する $(\mathrm{J})$ 事例がみられる。これは業者側が今後 の建替事業の実験との意味からぎりぎりの採算ラインで行ったこと、 また合意しなければ事業が実現できないため意見を取り入れざるを 得なかったことによると考えられる。

以上の合意形成は主に特命形式にみられるものであり、コンペ形 式では推進組織が複数案の中から最もよいものを選択し提示するこ とで計画変更の手間をなくすとともに、計画の相対的な最適性を明 らかにして内容に関する対立を回避しているといえる。またコンサ ルタントへの依頼により第三者の客観的な判断を得ていることも効 果的に働いている(D2,H2)。

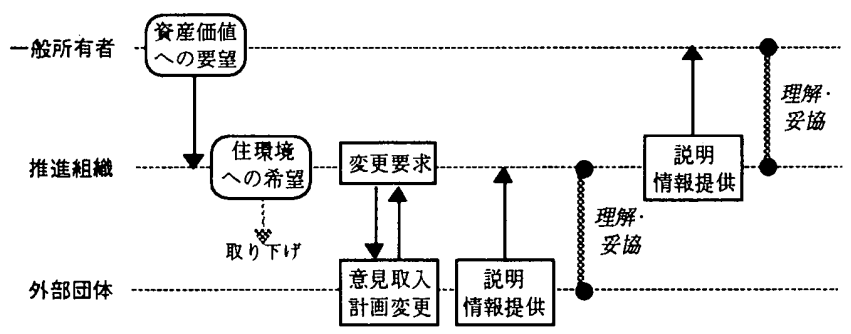

図 7 :「計画の内容」に関する合意形成

\section{3) 進行の方法}

この諭点に関する議論は、情報の提供や意向取入の不足などの所 有者対応の問題と、手続きへの異議や推准組織の権限に関する判断. 調整の仕方、及び合意の確認方法の 3 点である。

所有者対応の問題は推進組織が所有者との交流を行うノウハウに そしいこと、また数少ない所有者のみで推進組織を運営しているた め行うべき活動に対して人手が足りず、結果的に対応が不可能とな ることが要因としてあげられる。判断・調整の問題は決定の手順や 組織の権限を所有者との間で確認しなかったためと考えられ、推進 組織へ決定を委任する形をとるもの $(\mathrm{C} 2, \mathrm{E})$ や組織結成の際に規約を 制定するもの $(\mathrm{A}, \mathrm{H} 2)$ では問題は起きていない。住戸選定でも事前に 調整方法をしっかり議論したものでは異論は起きにくい(J等)。

合意の確認では多くの事例で総会等の場で所有者全体で確認する 形がとられている。検討期の方針認可ではアンケートの賛成多数を もって合意とみなす場合もあり、建替決議に賛否を提示したり（J） 同意書を集める $(\mathrm{E}, \mathrm{L})$ など明確に確認を行う事例はあまりない。こ れは所有者全体で意思決定をするというよりは所有者毎の合意をつ みあげる進め方がとられているためであるが、各段階での合意が全 体で明示的に確認されないため問題が生じているといえる。

これらの点に共通する要因として、早期の実現を目指すため時間 のかかる所有者との交流がおろそかになることも挙げられる。早期 実現が重視されるのは、老朽化が深刻になったため急逐建替の検討 が始まったこと、及び過程中にも設備の劣化が進んでいることによ ると思われる。また自分が期待する業者が選定されないことや住戸 重複の抽選で外れたことに反発するなど、意向が通らないことを運 営上の不備として提起する所有者側の問題もあるといえる。

対応としては基本的に指摘された点が改善されるが、対立が深い 場合はこれまでの活動・決定を一度保留した上で、推進組織のメン バーを入れ換えたり (C2,D2)、コンペをやめ法人所有者への特命にす る(C2) 等の変更を行い新たに策定をやり直すものもある。改善では 情報提供に関しては説明活動をより丁寧に行う、意向把握では所有 者の意見を再度把握し検討する (F2,M2)、決定方法ではその過程及び 判断基準を明確に提示する、合意方法ではコンペ形式で所有者投票 での選定を行う (D2,M2) などを行っている。これらを外部団体が支 援しており、説明会による情報提供や個別訪問での意向把握などき

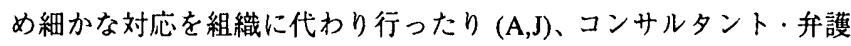
士が運営面や判断基準のアドバイスを行うなどしている (D2,H2)。

以上の対応で問題点が改善されることで、異議を唱える所有者が 納得し合意が得られている。このほか推進組織が自らの行為に問題 がないと判断する場合、反対する所有者への説明・説得を行い、所 有者を理解させてそのまま事業を進めるものもある (I,L 等)。

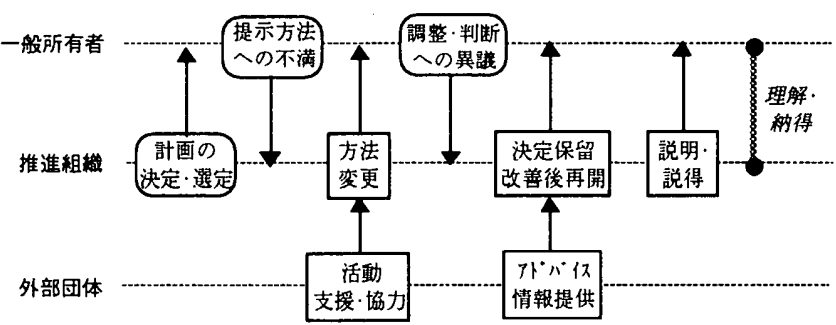

図 8 :「進行の方法」に関する合意形成 


\section{4-2。椎遥組䋖の役割}

以上の合意形成のメカニズムをみると、推進組織の果たす行動が 合意形成に大きな影䭗を及ほすといえる。そこで推進組織と他主体 の関係に着目して各事例での主体問関係をみると、(1)一般所有者に 建替の実施及び計画を提案する場面、(2)外部団体の計画提案に対し て意見・要望を提示する場面、(3)一般所有者·外部団体加提示さ れた意見を独自に判断・整理する場面、の 3 つに整理することが出 来る。こ机らは 2 -1での捉え方に基づけば、(1) 計画を「提案」す る主体 1、(2) 提案に対し「要望」する主体 2、(3) 各主体の意見及 び両主体間の関保を「調整」する第三者、という役割をそれぞれ担っ ているといえる。これらの役割は [図 9] のように示すことが出来、 以降では各役割としての推進組織を、それぞれ「提案主体」「要望主 体」「調整主体」と表記する。

この梘点に基づいて各事例での過程をみると、各役割に応じた 3 つのタイプに類型化することが出来る。一つは推進組織が提䋈主体 の役割を中心に行動し、推進組織と外部団体とが合意した計画を前 提としてその内容を一般所有者に説得し理解を得て合意する「説明

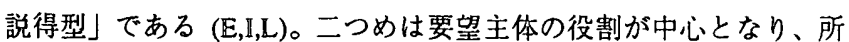
有者の意見を計画に取り入れさせることで合意を形成する「意見取 入型」である。これには推進組織と一般所有者が協力して外部団体 に対し意見を提示する場合 $(\mathrm{A}, \mathrm{C} 2, \mathrm{G})$ と、推進組織と外部団体が協力 して一般所有者の意向を受け入れる場合 $(\mathbb{F}, \mathrm{J}, \mathbb{K})$ とがある。三つめは 調整主体として活動し、コンペ形式の手続を適切に進めることで合 意を得る「手続重視型」である $(\mathrm{Cl}, \mathrm{D}, \mathrm{H}, \mathrm{M})$ 。この他 3 主体が一体と なって各役割を担い協力して計画を策定する事例 (B) がある。

これらのタイプの特徴を考察すると、説明説得型では短期間の作 業で計画は策定できるが、その内容が所有者の意向を満たさないと 説得は困難であり、また意向の反映や計画の公平性が手続上問題に なると思われる。意見取入型では所有者にとって望ましい計画が策 定されるが、計画を何度も変更しつつ合意を進めるので手間と時間 がかかる。また条件が悪く意見の取入が困難だとこの方法は難しい。 手続重視型では手続への共通理解を得ることによって円滑かつ適切 な計画の選定が出来るが、手続に関するノウハウが必要であるとと もに実務も多大になる可能性がある。

提琵主信 一般所有者提筑

図 9 : 推進組織の役割のタイプ

\section{5.まと虰}

以上の分析により明らかになったのは次の点である。

1）合意形成の過程全体は、構想・計画内容·実施設計等、個別の 㹎題への合意の集榬として捉えることが出来る。

2）合意形成においては建替の是非・計画の内容・進行の方法の 3 点が主要な論点であり、これらに関して主体間の交流が行われる。

3）論点に関する合意は、十分な意見交流を行い所有者の理解を得
ること・所有者の要望を满たす計画を策定すること・運営面での手 続を適切に行うこと、によって成立している。

4) 過程では推進組織が中心的な主体として活動しており、提案·要 望・調整の各役割に基づいた対応により合意が得られている。

今後行われるであろう建替事業の場合、事例 Bの上うに自己負担 が必要で条件が悪くなると予想されるため、推進組織が提案·要望· 調整の各役割においてより適切な対応をとらなければならない。こ れらの㹎題を知識・経験の少ない所有者のみで解決するのは困難と 思われ、法的な形での運営手続の確立や、実務や経験面を支援する 専門的職能が必要になるといえる。また同時に所有者の幅広い意向 に対応できるよう、権利を売却して参加しないことも含めた上で、状 況に応じた選択が可能にする必要があると思われる。

\section{注}

1）1995年の阪神·谈路大霆災で被災したマンションに関して、建替の際の合 意形成上の問題を報告する文献 11 等があるが、研究論文として分析を行った ものは現時点ではあまりみられない。

2) 3 主体のうち一般所有者はヒアリングの対象からは外れているが、これは 多效の所有者から広く話を聞くことは因難なためであり、推進組織及び外部団 体に各所有者の意見・行锄を問うことで必要な情報を得ている。また事例 B Cでは推進組織のヒアリングが行えなかったが、外部団体のヒアリンク及び各 種資料により必要な情報が得られたため対象事例とした。

\section{参考立就}

1) 前田昭彦 ·内田雄造：分譠マンションのリニューアルをめぐる諸問題一同 閏会アパートの建て替六問題をめぐって, 日本都市計画学会学術研究諭文篹第 25 号, pp757-762, 1990.11

2）米野史煡・原科幸彦：分讓マンション建替の事業実施過程に関する研究一 首都国における実現事例を対象として, 日本都市計画学会学術研究論文篹第28 号, pp157-162, 1993.11

3）高見沢邦郎・吳咗一郎：初期に建てられた分露マンションの実態と建替え 問題の今後の方向性について, 日本建築学会計画系論文報告箱第404号, pp8997, 1989.10

4）吳咗一郎・高見沢邦郎：初期の分境中高層集合住宅の実態と建替えへの問 題点についてーその3.建替えタ亿プの設定と夕イ゚別搆成比の推定, 日本建築学 会大会学術講演梗概集, pp379-380, 1990.10

5) 斉藤広子：篹合住宅管理研究の動向に関する考察ーマシション管理を中心に，マ ンション管理研究の 10 年と展望, 日本建築学会, pp 33-38, 1995

6) 畭亭·延藤安弘・森永良丙：価値づくりの計画プロセスにおける住み手の

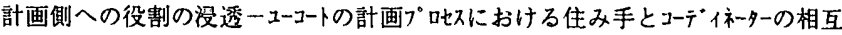
浸透性 1，日本建築学会計画系論文報告集第 446 号, pp53-63，1993.4 7) 中村昌広：東京都区部における行政発意による改善型まちづくりの計画形 成過程一計画案の变僄と住民参加, 日本都市計画学会学術研究論文集第21 号, pp313-325, 1986.11

8）早田宰・佐藤滋：住懪境整梢事業における目標岱問イメージの合意形成フ ロセスに関する研究, 日本建筇学会計画系論文報告集第 473 号, pp101-111, 1995.7

9) (財) マンション管理センター：分謢マンション建替の円滑な推進方策に関 する調査研究報告整, 1990

10) (財) トラスト 60 : マンション建替えに関する調查研究 (完) 報告害, 1990 11) 日経アーキテクチュア䋵：鬿る11棟のマンション, 日経BP社, 1997

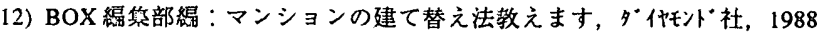
13) 山本理：マンション建替えを巡るユーザ意龍についての考察一生活と資産 の区分の視点加ら，都市住宅学第 12号，pp36-41，1995.12

14）楜瀬孝雄：紛争と载判の法社会学, 法律文化社, 1992

なお本研究は、文部省科学研究賓補助金 (特別研究員奖励筫)による研究成 果である。

（1997年 6 月10日原稿受理，1997年10月 7 日採用決定） 